\section{緒}

高粘性ニュートン流体または高粘性非ニュートン流体 の混合においては槽内全体上下方向にわたって液を強制 循環せしむる形式の翼が必要である ${ }^{3,10,12)}$ 。この形式の 翼としてはへリカルリボン翼, 案内円筒付きスクリニー 翼，掞よび上下動翼が挙げられるがこれらの翼について の伝熱実験の報告例は数少なく, 水科ら ${ }^{77}$, 永田ら ${ }^{13,14)}$, Coyle ら ${ }^{1)}$, 抢よび三石ら ${ }^{5)}$ の報告の数例に止まるうえ 飞研究者相互の一致は芳しくない。

アンカー翼に関する高粘性流体の擋拌伝熱実験は比較 的数多〈報告されているが2,6,8,16 19), 水科ら ${ }^{7)}$ や Coyle $ら^{1)}$ が述べているように $R e$ 数数十以下では槽内の温度 斑が著しくなり伝熱係数算出の際の液温度の決定に問題 が残る。本報告においては広範囲の $R e$ 数域にわたって ヘリカルリボン翼, 上下動翼, およびアンカー翼に対す る擋拌伀熱係数を測定し従来報告されている值と比較し 検討を加えてみる。また擋拌槽内の温度分布を測定して ヘリカルリボン翼とアンカー翼の混合性能についての比 較も行ってみる。

\section{1. 実 験 法}

\section{$1 \cdot 1$ 実験装置}

リボン翼拉よびアンカー翼についての実験に用いた擋 拌槽は熱的平衡を保つために伝熱壁面を 4 等分して加熱 用ジャケットと冷却用ジャケットが交互に設けられてい るが詳細は前報に述べてある13)。また Fig. 1 亿示すよ うに槽壁全面を加熱部とし内部に冷却用ドラフトチニー ブを設けて熱的平衡を保った場合についてのリボン翼槽 壁側伝熱係数を求めて比較を行った。

上下動翼の場合は Fig. 2 に示すように加熱および冷 却用の伝熱管を設けて搔き取り伝熱を行い熱的平衡を保 った。な抢使用した翼の寸法その他は Table 1 に示す。

\section{$1 \cdot 2$ 試 料}

ニニートン流体として水，グリセリン水溶液，水飴， およびシリコーンオイルを，擬塑性流体としては CMC 拈よび PVA の各種濃度の水溶液を擋拌液に使用した。 物性值は Table 2 に示されている。

\footnotetext{
* 新日鉄化学 (株)
}

\section{の 擋 拌 伝 熱}

西川正史・鎌田昇*

(故) 永 田 進 治 京都大学工学部 化学工学科

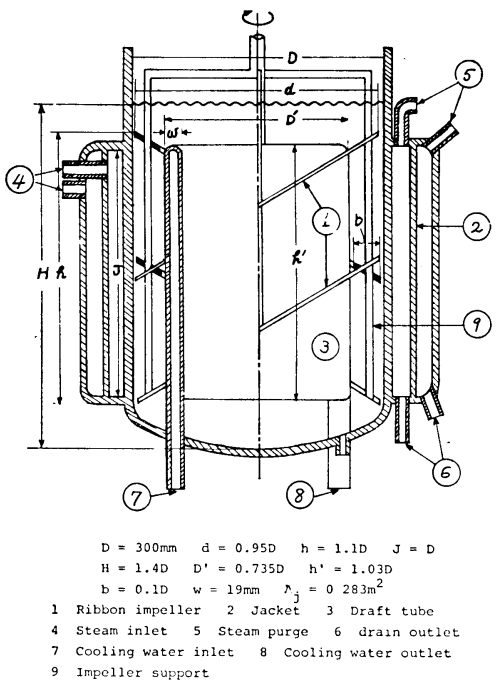

Fig. 1 Mixing vessel with draft tube for heat transfer

\section{$1 \cdot 3$ 伝熱係数の算出}

加熱部の伝熱量は蒸気㠜縮量より, 冷却部の伝熱量は 冷却水の熱収支より求めた。両者の差違は最大 $10 \%$ 程 度であったが伝熱係数の算出にあたっては両者の平均值 を使用した。加熱部の伝熱係数の算出にあたって蒸気㠜 縮側の伝熱係数は Nusselt の蒸気膜状凝縮の式 ${ }^{15)}$ を使用 した。冷却部の泠却水側伝熱係数は槽内条件を一定にし て冷却水量を種々变光た予備実験汇より求的た。

\section{$1 \cdot 4$ 見かけ粘度の決定}

擬塑性流体の見かけ粘度は動力相関の場合に得られた 槽内平均剪断速度と流動曲線より求めた。各翼に対する 槽内平均剪断速度や粘度決定の詳細については前報 ${ }^{11,14)}$ を参照されたい。

\section{2. 結果および考察}

\section{$2 \cdot 1$ ヘリカルリボン翼}

ヘリカルリボン翼に対する伝熱相関図が Fig. 3 亿示 されている。同図より明らかなように層流域汇おけるRe 数の勾配は $1 / 3$ で, 粘度補正項 $V i s$ の指数も 0.2 が妥当 であったがこれは前報の結果と一致する。 Pr 数の指数 が 1/3であることも確かめたので伝熱係数に与兄る粘度 の影響は層流域に批いてはVis の中に含まれるだけと なってしまう。これは伝熱面上泟形成される境界層の厚 みが壁面と翼端の間隚よりも厚くなるために熱伝達面の 
Table 1 Impeller used

\begin{tabular}{|c|c|c|c|c|c|}
\hline & $D$ & $d$ & $b$ & Pitch & $\begin{array}{l}\text { Blade } \\
\text { number }\end{array}$ \\
\hline Helical ribbon & 300 & $240,264,280,284,290$ & 28.5 & 1.0 & 2 \\
\hline Up-Down impeller & 200 & • 192 & - & - & 1 \\
\hline Anchor & 300 & $240,265,275,285$ & 28.5 & - & 2 \\
\hline
\end{tabular}

Table 2 Materials used

\begin{tabular}{lcccc} 
& $\left.\begin{array}{c}\rho \\
\mathrm{kg} \\
\mathrm{m}^{3}\end{array}\right]$ & $\left.\begin{array}{c}C_{p} \\
{\left[\frac{\mathrm{kcal}}{\mathrm{kg} \cdot{ }^{\circ} \mathrm{C}}\right]}\end{array}\right]$ & $\left.\begin{array}{c}k \\
\mathrm{kcal} \\
\mathrm{m} \cdot \mathrm{hr} \cdot{ }^{\circ} \mathrm{C}\end{array}\right]$ & $\begin{array}{l}\mu \text { or } \mu_{a} \\
{[\text { poise }]}\end{array}$ \\
\hline Water & 1,000 & 1.0 & 0.512 & 0.01 \\
Millet jelly & 1,450 & 0.57 & 0.36 & $1 \sim 150$ \\
CMC solution & 1,000 & 1.0 & 0.512 & $0.5 \sim 900$ \\
PVA solution & 1,000 & 1.0 & 0.512 & $0.2 \sim 50$ \\
Glycerin & 1,200 & 0.70 & 0.25 & $0.5 \sim 10$ \\
Silicone oil & 970 & 0.36 & 0.137 & $450 \sim 920$
\end{tabular}

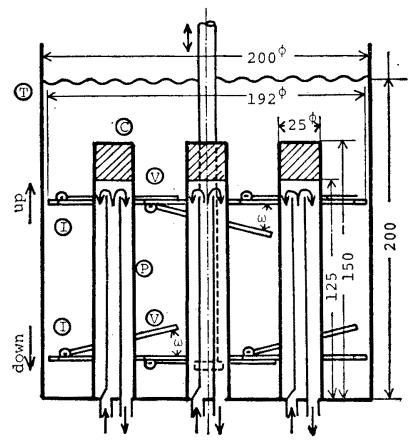

Fig. 3 Heat transfer correlation for helical ribbon impellers
Fig. 2 Details of up-down impeller

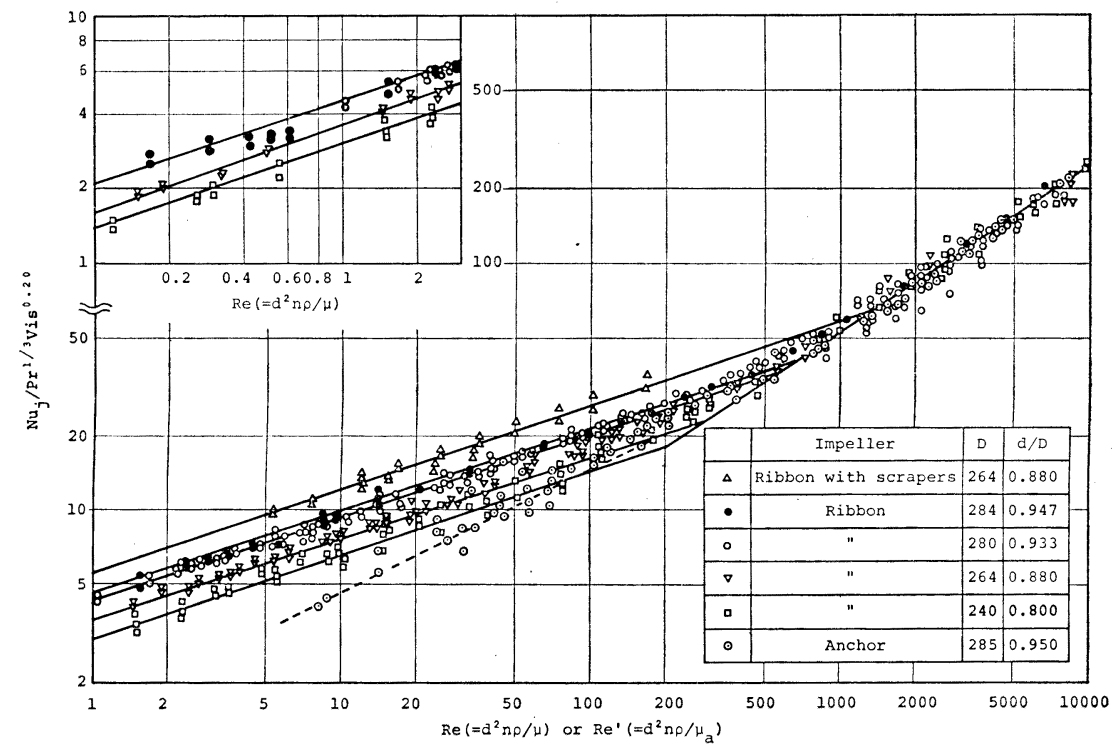

層の厚みが粘度に制関係となり間隙距離に一定するため と考えられる。したがって翼径さ大にして間隌距離を小 とすると熱伝達面の層厚みが減少して伝熱係数が增加す ることが予想される。Fig. 3 および Fig. 4 は間吵距離 を縮小していった場合の伝熱係数の増加の様子を如実に 示している。これらの結果を基にしてりボン翼に対する 槽壁側層流伝熱係数は次のように示される。

$$
N u_{j}=1.75 \operatorname{Re}^{1 / 3} \operatorname{Pr}^{1 / 3} \operatorname{Vis}^{0.2}\{(D-d) / d\}^{-1 / 3}
$$

上式の成立する範㑑は次のとおりである。

$$
0.1<R_{\mathfrak{c}}<R e_{c}, \quad 0.8<d / D<0.97
$$

ただし $R e_{c}$ は次のように表される。

$$
R e_{c}=39 \mathrm{D} /(D-d)
$$

翼径 $264 \mathrm{~mm}$ のリボン翼の翼端に2枚のゴム製の搔き取り 板をつけた場合の伝熱係数は次式のように相関された。

$$
N u_{j}=5.4 \operatorname{Re}^{1 / 3} \operatorname{Pr}^{1 / 3} \operatorname{Vis}^{0.2}
$$

搔き取り板による伝熱面の更新が理想的に行われる場 合には後述のように $R e$ 数の指数は $1 / 2$ でなければなら ないので，本実験結果は搔き取りが完全には行われてい

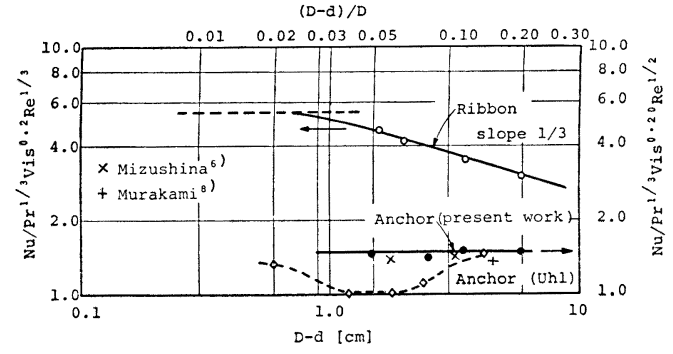

Fig. 4 Effect of clearance on heat transfer coefficients for Ribbon and Anchor impellers

ないことを示している。しかし伝熱係数は搔き取り板を つけることにより大きく向上している。

Fig. 3 より明らかなように乱流域に入ると伝熱式は槽 径比にかかわらず同じとなり次式で表される。

$$
N u_{j}=0.52 \operatorname{Re}^{2 / 3} \operatorname{Pr}^{1 / 3} V_{i s} s^{0.14} \quad R e_{c}<R e<10^{6} \quad \text { (4) }
$$

乱流域では円周方向流が支配的となって槽径比にかか わらず同一相関式が得られるのであろう。 


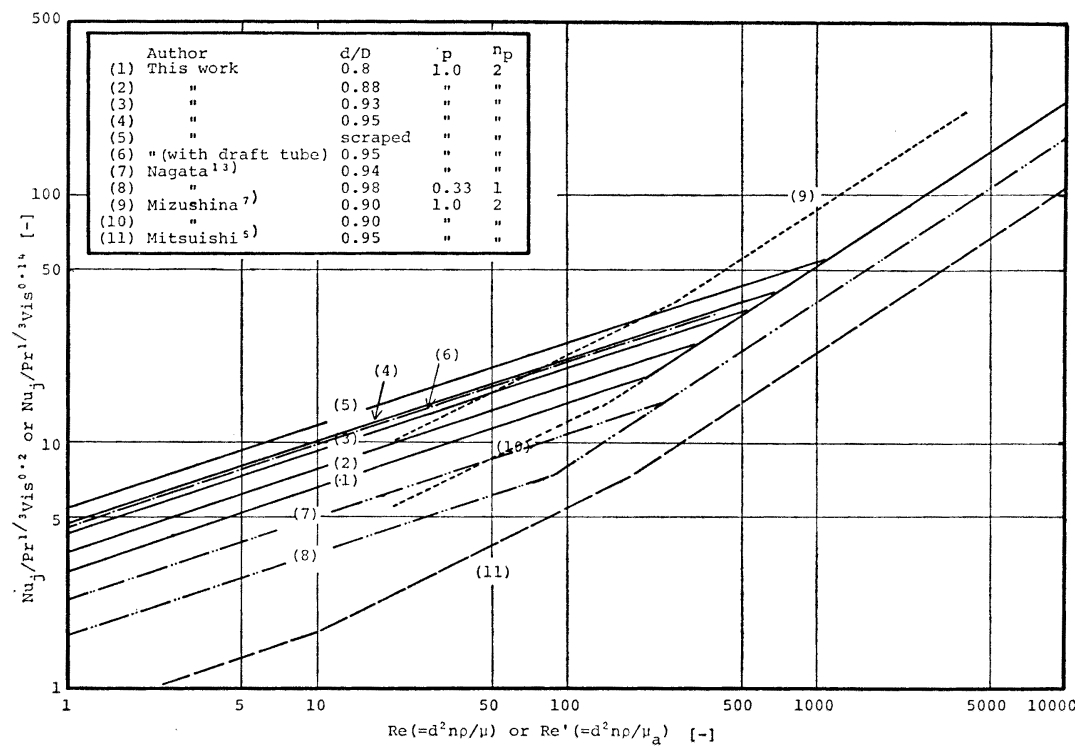

Fig. 5 Heat transfer correlation for helical ribbon impellers by several authors

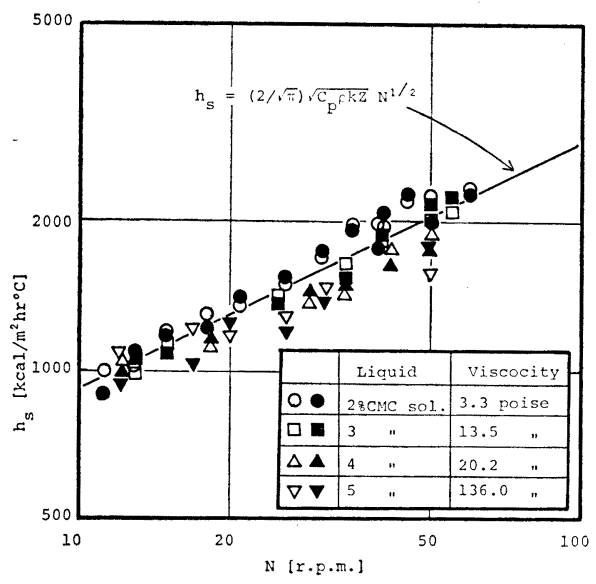

Fig. 6 Scraped heat transfer coefficients for up-down impeller

Fig. 3 には擬塑性流体に対する結果もニュートン流体 に対する結果も同時にプロットしたが，流体の性質によ っては伝熱相関結果に差がつかなかった。動力基準の槽 内平均の見かけ剪断速度と流動曲線（擬塑性流体の流動 曲線が指数法則やその他のモデル式に合致するしないは この方法では問題とならない）ょり求めた見かけ粘度 が槽壁よりの伝熱相関に充分の精度で使用できるわけで ある。もっとも層流域では前述のように伝熱係数に与え る粘度の影響は消えてしまうので粘度の大小そのものが 問題とならないことは興味深いことである。なお 4 分割 ジャケットを使用した場合には, 断熱部から加熱部また は冷却部にかけて形成される伝熱境膜の助走区間の影響 で， $h_{j}$ の值が槽壁全体を加熱部に使用する場合に比べ てやや高くなることが考兄られる。しかし Fig. 5 の曲 線（4）と（6）に示されるように 4 分割ジャケットと案
内円筒設置の場合で伝熱係数の差は数\%しかないこと, PVA の加熱部壁面への熱重合膜厚みが断熱部から約 2 $\mathrm{cm}$ の所まで他の部分に比べて薄くなったことを考慮す ると助走区間の与える影響は約 $10 \%$ 程度と思われる。

また Fig. 3 には 4 分割ジャケットの場合と案内円筒 設置の場合の測定点を同時に点経してあるが両者はよく 一致した傾向を示している。

Fig. 5 にはリボン翼に対する伝熱相関の報告例が比較 して示されている。水科ら ${ }^{7)}$ はスチレンの塊状重合を行 い発熱量をジャケットにより冷却する方法で伝熱係数を 得ているが，撹拌速度によって伝熱相関式が変化してい る。これはこの実験法が非定常伝熱に属し, 反応進行に ともなって粘度が急激に上昇するため槽内現象が複雑と なるためと考えられる。水科らの実験值は本実験の結果 とほぼ一致しているといってよかろう。Coyle ら は1 枚羽根リボン翼でジャケット冷却による非定常伝熱を行 い, 同じ槽径比のアンカー翼より 25 30\%大なる伝熱 係数の得られたことと, 高粘度液になると粘度が伝熱係 数に影響を与えなくなることを報告している。翼枚数や ピッチの影響を考慮すると ${ }^{14)} ， 2$ 枚羽根でピッチ1のリ ボン翼ではアンカー翼の約 2 倍の伝熱係数が得られるこ とになるがこの值は本実験の結果に近いものである。

コイル状リボン翼の伝熱係数が低くなっているのは, コイル状リボン翼がパイプで作られていたため平板で作 られたリボン翼よりやや性能が劣るためと考えられる。 なお三石らの実験値はアンカー翼に対する伝熱相関よ りもかなり小となっているが他の研究者に比較して低す ぎるようである。

\section{$2 \cdot 2$ 上下動翼}

Fig. 6 は上下動擋拌翼による搔き取り伝熱係数を擋拌 
Fig. 7 Heat transfer correlation for anchor impellers

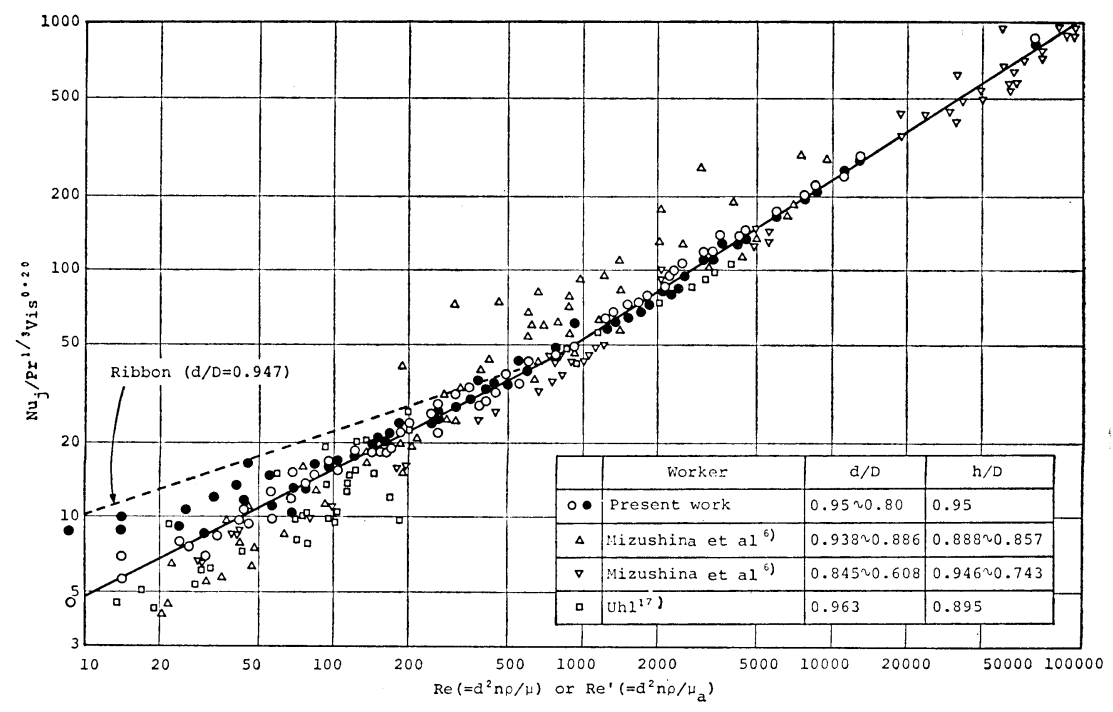

周期に対して点綴した図である。

伝熱面が周期的に搔き取られている時掻き取り面の流 体境膜の状態は時間的に，また局所的に非定常な状態に あって絶えず周期的な境膜の生成と消隇を繰り返す。

$\mathrm{Kool}^{4)}$ はこのような場合に対して 1 次元非定常理論よ り次式のような掻き取り境膜伝熱式を提出している。

$$
h_{s}=(2 / \sqrt{\pi}) \sqrt{C_{p} \rho k Z n}
$$

ここで $Z$ および $n$ はそれぞれ擋拌 1 周期に伝熱面が 搔き取られる回数と撹拌周期を意味している。

Eq.（5）より搔き取り伝熱係数は液粘度には影響され ず摚拌周期の $1 / 2$ 乗に比例することになる。したがって Fig. 6 より明らかなように上下動翼は良好な搔き取りを 行っていることがわかる。 $\mathrm{CMC}$ 水溶液の物性值を Eq. （5）に代入すると Eq. (6) が得られるが Fig. 6に示され ているようにこの式は測定点をよく代表している。

$$
h_{s}=289 \mathrm{~N}^{1 / 2}
$$

なお Fig. 6に見られるように粘度の高い場合には擋拌 周期の大なる場合に理論線より低くなる傾向がある。

これは伝熱管外壁と搔き取り板が完全には密着してお らず局部的には $1 \mathrm{~mm}$ を越す間隙ができているため液粘 度が高くなるにつれて搔き残された層での伝熱抵抗が大 きくなるため実験值が理論線より低くなるものと考兄ら れる。なお翼の機構的理由から槽壁伝熱係数も Eq. (5) でよく相関されると考兄られる。本装置のよらに往復搔 き取り運動を行う場合には場所によって搔き取り周期に 差ができる。このような場合には $h_{s}$ は理論的には同じ 周期で搔き取られる場合の $2 \sqrt{2} / 3$ 倍になるが，その補 正値は小さいので本実験においては簡単のため平均的に みてどの場所も同じ周期で搔き取られるとした。

境膜伝熱係数の值を上下動 1 周期を擋拌翼 1 回転と同 じとみなして比較すると, 上下動翼の伝熱係数は他の翼
に比べて最も高い値となる。混合時間もリボン翼より短 (12)ので上下動翼は高粘性流体の擋拌伝熱に適している。

\section{$2 \cdot 3$ アンカー翼}

アンカー翼に対する伝熱係数の相関結果が Fig.7に示 してある。この図より明らかなように従来の報告結果は ほぼ一致しており次式で相関される。

$$
\begin{array}{ll}
N u_{j}=1.5 \operatorname{Re}^{1 / 2} \operatorname{Pr}^{1 / 3} \operatorname{Vis}^{0.20} & 50<R e<500 \\
N u_{j}=0.52 \operatorname{Re}^{2 / 3} \operatorname{Pr}^{1 / 3} \operatorname{Vis}^{0.14} & 500<\operatorname{Re}<10^{6}
\end{array}
$$

乱流域における伝熱相関式はリボン翼の場合と同じで あるが層流域では低くなっている。なお Zlokarnik ${ }^{19)} や$ 村上ら ${ }^{9}$ はアンカー翼の場合にも低 $R e$ 数域における $R e$ 数の指数は $1 / 3$ になると報告している。

しかしこの点についてはより多くのデータによる検討 が必要である。またアンカー翼の場合には後に述べるよ らに槽内液温度にかなりの斑が生じたり, 温度が時間的 に変動したりするので, 伝熱係数算出の際の温度差推進 力の採り方がむずかしくなる。Fig. 7 に示されるように $R e$ 数が 50 以下になると伝熱係数にバラッキが増し良 好な相関関係が得られなくなる。なお Fig. 4 に示され るよらにアンカー翼の場合には槽壁と翼との間吵距離の 変化にもかかわらず伝熱相関式に差違はつかなかった。 Uhl ${ }^{18)}$ は Fig. 4 に破線で示したよらな变化のあること を報告しているが，水科 ${ }^{6)}$ や村上 ${ }^{8)}$ の結果も著者らの 結果とほぼ等しい値を示している。この点についてはさ らに詳しく検討も必要であろらが, 層流域のアンカー翼 擋拌伝熱においては温度斑や混合の進行の遅いことなど を考え合わせると厳密に間隙距離の影響を測定データよ り検討を加えることはやや無理なように思われる。なお アンカー翼の垂直翼部をパイプで作成した場合も平板の 垂直翼の場合と同じ伝熱相関式でまとめることができ た。 


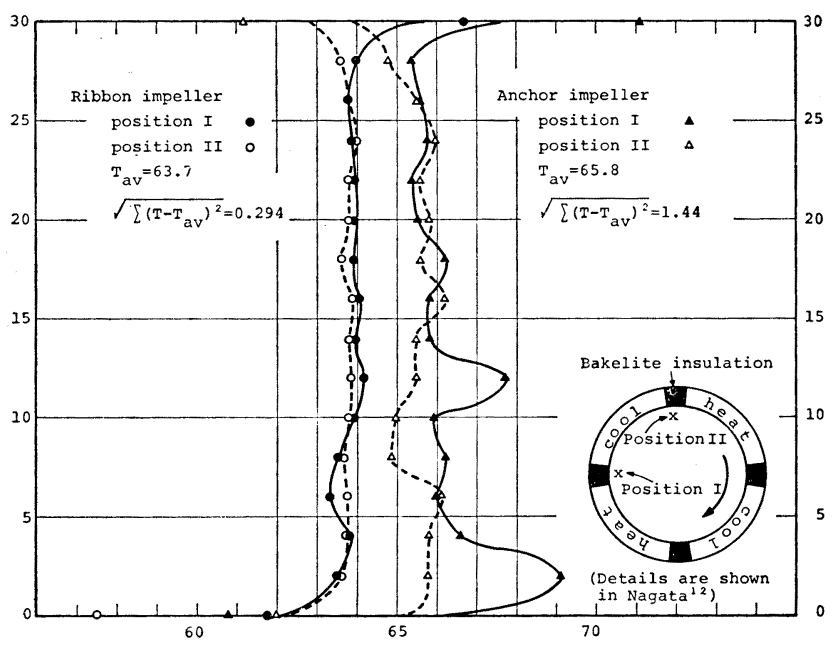

Fig. 8 One example of temperature distribution of liquid near the wall surface ( $15 \mathrm{~mm}$ from the wall surface)

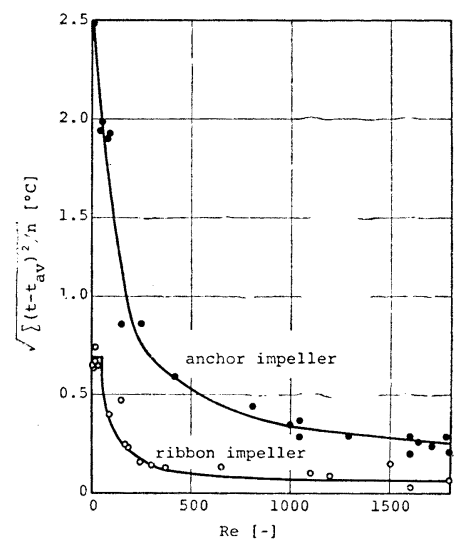

Fig. 9 Distribution of liquid temperature (average of 6 positions). Jacket temperature ${ }^{*}$ heating side $100 \sim 100.5^{\circ} \mathrm{C}$, cooling side $15 \sim 25^{\circ} \mathrm{C}$

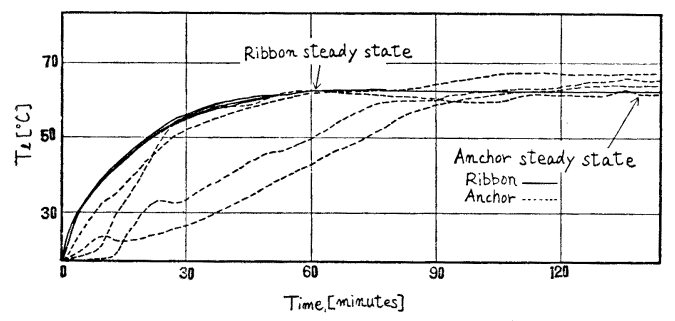

Fig. 10 Change of liquid temperature after start-up of heating ( $N=20 \mathrm{rpm}$, millet jelly 15.7 poise)

\section{$2 \cdot 4$ 槽内の液温の分布}

Fig. 8はリボン翼およびアンカー翼擋拌の場合の定常 状態達成後の槽内の液の温度の分布を比較したものであ る。この図よりわかるようにアンカー翼の場合には液温 度の分布が大きく混合状態はよくない。

Fig. 9 は $R$ 数を变化した時の槽内 6 点に和ける液温 度の偏差值を示している。図より明らかなようにリボン 翼の場合には $R e$ 数が数十以下でも標準偏差は $0.8^{\circ} \mathrm{C}$ 以 下で温度斑はほとんどなく平均温度の採り方にも問題が 起こらない。一方アンカー翼の場合には $R e$ 数が 100 の 場合で $1.5^{\circ} \mathrm{C}, 50$ の場合で $2^{\circ} \mathrm{C}$ と標準偏差は大きくか なりの温度斑のできていることがわかる。このためアン カー翼の場合には槽内液の平均温度の採り方に問題が残 るわけである。またアンカー翼の場合には温度斑の大き さより考光てもとの使用範围は $R e$ 数数十以上に限定す るのが妥当と思われるので，それ以下の低 $R e$ 数域にお ける実験を行ら意味そのものが薄いようである。

水科ら ${ }^{7)}$ もンカー翼擋拌の場合には $\operatorname{Re}$ 数が 50 以 下になると急激に温度斑が増すことを報告している。こ のよらな場合にはアンカー翼翼端に掻き取り板をつけて も槽内液の混合が覀いため大した効果はあがらないこと が予想される。
Fig. 10 は摚拌伝熱䦎始後の槽内液の温度の経時変化 をリボン翼とアンカー翼について此較したものである。

リボン翼の異合には各点の温度は同じように対数曲線 的に増加し速やかに定常状態に達するのに対して, アン カー翼の場合の各点の温度の上䅫様式には統一性がな く, 定常状態に達するまでの時間がリボン翼の 2 倍以上 かかるらえに定常状態達成後の各点の温度にかなりの差 がみられる。したがって非定常法によって伝熱係数の測 定を行う場合にはリボン翼に関しては問題が起こらない が, アンカー翼の場合にはどの点の液温度を代表点に採 用するかによって伝熱係数に大きな差がつくので注意す る必要がある。

ただしりボン翼擋拌の場合で斥，本実験に使用した形 式の翼の場合には液の粘度にかかわらず 6 RPM 以下の 低撹拌速度では良好な撹拌状態が得られなかった。つ まり槽内の平均剪断速度が数 $\mathrm{sec}^{-1}$ 以下になるとリボン 翼擋拌の場合にも混合斑が出現したのでリボン翼は 10 RPM 以上で使用するのが無難なようである。無論この 最低有効擋拌速度は槽径の変化に対応して変わることが 予想される。

\section{結竟}

1）リボン翼に対する高粘性非ニニートン流体の撹拌 伝熱式として次式を得た。

$$
\begin{array}{r}
N u_{j}=1.75 \operatorname{Re}^{1 / 3} \operatorname{Pr}^{1 / 3} \operatorname{Vis}^{0.20}\{(D-d) / D\}^{-1 / 3} \\
0.1<\operatorname{Re}<\operatorname{Re} e_{c} \\
N u_{j}=0.52 \operatorname{Re}^{2 / 3} \operatorname{Pr}^{1 / 3} V_{i s^{0.14}} \quad \operatorname{Re}_{c}<\operatorname{Re}<10^{6}
\end{array}
$$

またりボン翼翼端に搔き取り板を取り付けた場合に対 して次の相関式を得た。

$$
N u_{j}=5.4 \operatorname{Re}^{1 / 3} \operatorname{Pr}^{1 / 3} V_{i s} s^{0.20} \quad 0.1<R e<10^{3}
$$

リボン翼擋拌の場合には $R e$ 数が 1 以下になっても混 
合は良好で槽内に温度斑はみられない。しかし槽内平均 剪断速度が数 $\sec ^{-1}$ 以下になると混合がやや不良となる ようである。

2）上下動翼擋拌の場合には搔き取り伝熱が有効飞行 われ伝熱式は 1 次元非定常理論よりの理論式と一致し次 式が成立した。

$$
h_{s}=(2 / \sqrt{\pi}) \sqrt{C_{p} \rho k Z n}
$$

3） アンカー翼擋拌の場合には $R e$ 数が 100 以下にな ると温度班が目立ちはじめ $R e$ 数が小になるにつれて急 激汇大きくなるので $R e$ 数数十以下には適しない。なお 伝熱相関式としては槽径比の影響がみられず次式が得ら

$$
\text { れた。N } u_{j}=1.5 \operatorname{Re}^{1 / 2} \mathrm{Pr}^{1 / 3} \mathrm{Vis}^{0.20} \quad 50<R e<500
$$$$
N u_{j}=0.52 \operatorname{Re}^{2 / 3} \operatorname{Pr}^{1 / 3} \mathrm{Vis}^{0.14} \quad 500<\operatorname{Re}<10^{6}
$$

4）擬塑性流体の伝熱相関においては動力相関の際に 求められた槽内平均剪断速度と流動曲線上り求められた 見かけ粘度を使用することによってニュートン流体の場 合と同じく良好な相関を得ることができた。この方法に おいては擬塑性流体の流動曲線がどのような模型でよく 近似されるかを問題としない。

\section{Nomenclature}

$$
\begin{array}{rlr}
C_{p} & =\text { specific heat } & {\left[\mathrm{kcal} / \mathrm{kg} \cdot{ }^{\circ} \mathrm{C}\right]} \\
D & =\text { diameter of mixing vessel } & {[\mathrm{m}]} \\
d & =\text { diameter of impeller } & {[\mathrm{m}]} \\
h_{j} & =\text { heat transfer coefficient at jacket wall } \\
& & {\left[\mathrm{kcal} / \mathrm{m}^{2} \cdot \mathrm{hr} \cdot{ }^{\circ} \mathrm{C}\right]} \\
h_{s} & =\text { heat transfer coefficient at scraped surface } \\
& & {\left[\mathrm{kcal} / \mathrm{m}^{2} \cdot \mathrm{hr} \cdot{ }^{\circ} \mathrm{C}\right]} \\
k & =\text { thermal conductivity } & {\left[\mathrm{kcal} / \mathrm{m} \cdot \mathrm{hr} \cdot{ }^{\circ} \mathrm{C}\right]} \\
N & =\text { impeller speed } & {\left[\mathrm{min}^{-1}\right]} \\
n & =\text { impeller speed } & {\left[\mathrm{sec}^{-1}\right]} \\
N u_{j}\left(=h_{j} D / k\right)=\text { Nusselt number } &
\end{array}
$$

$\operatorname{Re}\left(=d^{2} n \rho / \mu\right)=$ Reynolds number for Newtonian

$R e^{\prime}\left(=d^{2} n \rho / \mu_{a}\right)=$ Reynolds number using apparent viscocity

$\operatorname{Pr}\left(=C_{p} \mu / k\right.$ or $\left.C_{p} \mu_{a} / k\right)=$ Prandtl number

$\operatorname{Vis}\left(=\mu_{w} / \mu\right.$ or $\left.\mu_{a w} / \mu_{a}\right)=$ viscocity correction term

$Z \quad=$ scraping frequency in one circle

\section{Literature cited}

1) Coyle, C.K., H.E. Hirshland, B. J. Michel and Y.J. Oldshue: Can. J. Chem. Eng., 48, 275 (1970)

2) Gluz, M.D. and A.S. Pavlushenko: Zh. Prikl. Khim., 39, 2323 (1966)

3) Hoogedoorn, C. J. and A. P. Den Hartog: Chem. Eng. Sci., 22, 1689 (1967)

4) Kool, J.: Trans. Instn. Chem. Engrs., 36, 253 (1958)

5) Mitsuishi, N. and Y. Miyairi : J. Chem. Eng. Japan, 6, 415 (1973)

6) Mizushina, T., R. Itoh, Y. Ikuta, S. Hiraoka, Y. Konaka and J. Watanabe: Kagaku Kōgaku, 31, 1208 (1967)

7) Mizushina, T., R. Itoh, S. Hiraoka and J. Watanabe: Kagaku Kōgaku, 34, 1205 (1970)

8) Murakami, Y.: Ph. D. thesis Kyoto Univ. (1965)

9) Murakami, Y.: Read in PACHEC (1972)

10) Nagata, S., T. Yanagimoto and T. Yokoyama: Kagaku Kōgaku, 21, 278 (1957)

11) Nagata, S., M. Nishikawa, H. Tada and S. Gotoh: $J$. Chem. Eng. Japan, 4, 72 (1971)

12) Nagata, S., M. Nishikawa, T. Katsube and K. Takaishi: Kagaku Kögaku, 35, 793 (1971) or Int. Chem. Eng., 12, 175 (1972)

13) Nagata, S., M. Nishikawa and T. Kayama: J. Chem. Eng. Japan, 5, 83 (1972)

14) Nagata, S., M. Nishikawa, T. Kayama and M. Nakajima: J. Chem. Eng. Japan, 5, 187 (1972)

15) Nusselt, J. : Z. Ver. Deut. Ing., 60, 541, 569 (1916)

16) Pollard, J. and T. A. Kantyka: Trans. Instn. Chem. Engrs., 47, 21 (1969)

17) Uhl, V.W. and G.R. Voznick: Chem. Eng. Progr., 50, 72 (1960)

18) Uhl, V.W. : CHISA Report (1969)

19) Zlokarnik, M.: Chem. Ing. Tech., 22, 1195 (1969)

(1974 年 10 月 21 日受理)

\title{
Heat Transfer for Highly Viscous Liquids in Mixing Vessel
}

\author{
Masabumi Nishikawa, Noboru Kamata* and the late Shinji Nagata \\ Dept. of Chem. Eng., Kyoto Univ., Kyoto
}

Despite the high performance of the helical ribbon impeller for mixing of highly viscous Newtonian or non-Newtonian liquids, reports about the heat transfer coefficients from the vessel wall agitated by a ribbon impeller are few and agreement of data among the authors is poor.

The correlative equations of heat transfer coefficients for Newtonian and pseudoplastic liquids in a wide range of viscosity (0.004 900 poise) agitated by helical ribbon impellers of various impeller diameters including scraping, are reported in this paper. Heat transfer coefficients for up-down and anchor-type impellers are also compared with those for ribbon impeller. Comparison of mixing performance measured by temperature distribution or temperature change with time in the mixing vessel showed that performance of ribbon was superior to that of anchor.

* Shin Nittetsu Kagaku Co., Ltd. 